\title{
Media-social behavior of Muhammadiyah members in China in the framework of Alexander Wendt's international communication constructivism
}

\author{
Dani Fadillah
}

Prodi Ilmu Komunikasi, Universitas Ahmad Dahlan, Yogyakarta, Indonesia.

Email:dani.fadillah@comm.uad.ac.id

Uspal Jandevi

Masters degree program in School of Comunication and Journalism, Nanjing Normal University, Nanjing, China

Email:0185309@stu.njnu.edu.cn

\begin{abstract}
This paper aims to determine how the social media behavior carried out by Muhammadiyah members in China after the Chinese government's viral repressive action towards the Uighur ethnic minority in the Xinjiang region. As an Islamic-based social organization, and even more geographically, both live in China, the Head of the Special Branch of Muhammadiyah China, the Nanjing Regional, certainly has its study regarding the issue which may have a different point of view from the views of most Indonesians on this matter and take action. to respond of the news that, the response of most Indonesians after the virality of the issue. Therefore, the author tries to explain how Muhammadiyah members' media behavior in China and their opinions to build amid Indonesian society after the viral news above uses constructivism logic developed by Alexander Wendt. This paper's conclusion shows that there are efforts by Muhammadiyah
\end{abstract}


cadres in China to calm the heating up the domestic atmosphere as a form of creating a more conducive atmosphere between China and Indonesia.

Keywords: Social Media, Muhammadiyah in China, Contructivism, Alexander Wendt.

\section{Introduction}

Nearly two decades ago, when the issue of globalization was being blown out, almost all people in the world thought that the United States would emerge as the champion in this global competition, given how superior the United States was at that time. However, a different view was given by James Meredith; at that time, he thought that the one who would become the champion in the global competition was not necessarily the United States, because from Asia two countries are secretly developing themselves and have the potential to overtake America, the two countries are India and China (Meredith, 2007). And now it seems that what Meredith predicted at that time came true, as a result of the consistency of the cultural revolution that had been carried out in the era of Deng Xiaoping's leadership, now China can compete in the global market and may even be said to be the winner in the age of globalization (Fadillah, 2020).

The various advances possessed by China inevitably make this country one of the main goals of people from different parts of the world for multiple purposes, from doing business to becoming one of the main goals of the world community to continue education, including one of the people who continue their studies at the most. China is originating from Indonesia (Fadillah et al., 2020).

However, after the viral coverage on Social Media regarding the Chinese government's repressive behavior towards ethnic Uighurs in Xinjiang, predominantly Muslim, a wave of protests emerged and the opposing views of the majority of Indonesians towards China (Makki, 2018). Responding to this problem, the Chinese Ambassador to Indonesia has clarified the news (Suastha, 2018). Still, the clarification has not succeeded in reducing the social upheaval that has arisen. Because indeed messages that are viral on social media today have tremendous power to stay longer in someone's mind (Jandevi, 2019), especially when it comes to controversy (Lotan, 2019), it is not surprising that the confirmation from the Chinese ambassador for Indonesia is not ignored by the people who have been exposed to this negative news first.

The Chinese Ambassador to Indonesia, Xiao Qian, clarified the news 
about the repressive actions of his country's government against Uighur Muslims. Xiao Qian claims the information about the Chinese government's repressive measures against Uighur Muslims is not valid. According to him, the Xinjiang region, which is home to many Uighur Muslims, is still safe. He also invited the Indonesian people to see the current condition of Uighur Muslims in China. Xiao Qian admits that there are problems in Xinjiang that are currently being handled by the Chinese government. Previously, the news about the Chinese government's alleged response to Uighur Muslims had become a conversation among many Indonesian citizens in the last few days. This issue had raised several hashtags related to Uyghurs on twitter, one of which was \#IndonesiaStandsWithUyghur (Idhom, 2019).

The Western mass media also contributed to making conditions less conducive to reporting. Earlier, the Wall Street Journal newspaper reported that the Chinese government-funded a group of delegates from Indonesia consisting of Islamic organizations and journalists to visit Xinjiang to gain international support and shape public opinion. The accusation that two of Indonesia's largest Islamic organizations were silenced by pouring out of funds from the Chinese government so as not to voice Uighur Muslims' suffering in Xinjiang, China, was immediately denied by Muhammadiyah and Nahdlatul Ulama (Amindoni, 2019).

We must be mindful that our society is still in the vortex of a posttruth company (Ulfah \& Barry, 2019), Previously, there was research on how high the literacy level of Muhammadiyah residents (Ulfah et al., 2017) showed unsatisfactory results. With the number of cadres and sympathizers of Muhammadiyah in this country, I believe viral information shows that even within the Muhamamdiyah institution, there is still a need to intensify media literacy campaigns.

Feeling that they have a stake and want to maintain a conducive atmosphere, cadres and sympathizers of Muhammadiyah, who are in China, are trying to calm the heated atmosphere because they are worried that the masses' emotions must be calmed because otherwise, it will potentially lead to things. Others that are not expected in the future and will not be suitable for both countries.

Therefore, on several occasions, to access social media, Muhammadiyah members, and sympathizers in China have tried to introduce Muslim's real conditions in China. Because they are Muhammadiyah members and sympathizers who happen to be in China to continue their studies, they are 
often contacted by their colleagues from Indonesia to confirm Muslims' condition in China.

Therefore, the author feels interested in researching Muhammadiyah cadres' behavior in China after the viral information about the repressive actions carried out by the Chinese government against the Uighur ethnicity. The data that the authors obtained in this study were dissected using Alexander Wendt's constructivism logic and then presented on the discussion page.

The discourse on constructivism about the address of communication between nations or what is commonly referred to as international communication began to emerge in 1989 after being introduced by Nicholas Onuf in his book "World our making," which was later developed by Alexander Wendt in his manuscript entitled "anarchy is what state. make of it" (Rachmawati, 2012).

Onuf argues that an event is not something independent, but an event can occur because it has been arranged by a force that deliberately designs it to appear. Therefore, based on the logic built by Onuf, it can be concluded that the information related to whatever happened between the Chinese government and the ethnic Uighurs and how then the response given by the majority of Indonesians to this issue is not something that runs naturally but has arranged and planned in such a way by an absolute force.

Wendt's constructivism then focuses on social discourse and communication between international communication actors, namely through the exchange of ideas and ideas they do. Wendt expressed, "actor use ideas to construct relationship and material reality. So ideas precede negotiations and interpret history to make relationships either conflictual or cooperative" (Asrudin \& Suryana, 2009).

Perfecting the logic built by Alexander Wendt, John Hobson maps constructivism in international communication in three variants (Hobson, 2000), including:

a. International Society Centric. In this variant, Hobson states that the international community's big interests and schedule can be influenced. The international community incorporated in a global organization can transmit specific ideas and discourses that can dictate a country's mainstream issues. The status of the Chairman of the Chinese Muhammadiyah Special Branch, who is directly in China, as well as the status of Muhammadiyah, who is generally actively involved in various international forums based on this variant, also have the opportunity to inject discourse to reduce the situation to create a more conducive atmosphere. 
b. State Centric Constructivism. In this variant, it is stated that basically, a nation wants to uphold security norms in its country and anywhere, economic security, politics, to the military. Therefore, the government of a country will not just accept the information carried by international organizations but will be sorted based on the priority of the state's interests.

c. Radical Constructivism. This variant is extreme because it starts to sue state institutions; in this variant, "state" is not the same as "sovereignty." In a country, various types of populations are not always the same. They feel forced to "have a sense of togetherness," he said, because they live in the same area when in fact, they don't know each other. People who are included in this type of variant can also be called "internal other."

Returning to Wendt's constructivism that the state does not have a given interest because the government is confined in a normative social message structure. After all, it is influenced by discourses developed by various other institutions (Nau, 2009); it is exciting to know-how is the effort made by the leadership of the Muhammadiyah China Special Branch to inject information to the public in the country after the viral story on the Chinese government's repressive behavior towards ethnic Uighurs through the social media behavior of members and sympathizers in China.

\section{Methods}

This research is qualitative research with a descriptive approach. Qualitative research methods are research used to examine natural objects' conditions, where the researcher is a crucial instrument (Sugiyono, 2013). The difference with quantitative analysis is that this research departs from data, utilizes existing theories as explanatory material, and ends with a view.

After analyzing several definitions of qualitative research, Sugiyono then created his purpose to synthesize qualitative research's main reports. According to Moleong, qualitative research intends to understand the phenomena experienced by research subjects such as behavior, perception, motivation, action, etc. in a holistic manner and using descriptions in words and language. A particular context that is natural and by making use of various natural methods (Sugiyono, 2016).

The author conducted interviews with several cadres and sympathizers of the Chinese Muhammadiyah, both inside and outside the management. Some are in Muhammadiyah's control; the writer conducts interviews with the Media 
and Information Council, the Muhammadiyah command's tip-in conveying messages to a broad audience. Meanwhile, outside of the author's management, I conducted interviews with cadres and sympathizers who were active in other organizations in China, such as the Chinese Indonesian Student Association and the Indonesian Assistance Movement organization. Given that there are not a few Muhammadiyah cadres and sympathizers who are active in other organizations but are still in line with the Life Guidelines for Muhammadiyah members.

After finding a clear path and format, the authors distributed questionnaires and conducted interviews with Indonesian students who become members of Muhammadiyah in China regarding their social media activity. They are diploma level students, undergraduates, postgraduates, and post-doctoral who have been living in the city of Nanjing for more than a year. The data obtained by the author was dissected using Wendt's theory of international communication. The results are then outlined in the paper presented in this paper.

Apart from conducting interviews with them, the author also looked at the content on social media statuses such as the cadres' Facebook, Instagram, Youtube, WhatsApp pages, and the non-Muhammadiyah organizations they were active in. Based on the data obtained, the author then dissects it using Alexander Wendt's Constructivism logic.

\section{Results and Discussion}

Muhammadiyah members in China want to promote peaceful diplomacy related to the Uighur issue. This is done to maintain Indonesia's stability while at the same time maintaining good relations between Indonesia and all friendly countries, including China. One of the goals of diplomacy to be beneficial is to prevent other countries from joining forces to fight against a particular country, in this case, Indonesia. This goal can be achieved through various means, such as negotiations for mutual understanding. It is hoped that we can work together well again because the state's interests are the primary factors that will regulate the choice of diplomatic methods to be used. It cannot be denied that war and peace are exclusive conditions that generate benefits for both parties. In both cases, diplomacy is significantly relied upon as a means of dampening. And this is what Muhammadiyah members in China are doing. 
From the interviews and observations of social media uploads that the author conducted on Muhammadiyah cadres and sympathizers in China, the authors found two types of social media behavior that emerged, namely: social media behavior which emphasized that Islam was very accepted and fully facilitated by the Chinese government, and secondly. Is the media behavior of Muhammadiyah members in China neutral and invites everyone to be careful in responding to news of the Chinese government's repressive action towards the Uighurs.

The author did not find any opinions and statistical uploads from Muhammadiyah members in China who emphasized that the Chinese government was in the wrong position, nor was there any social media behavior that suggested that there was repressive action by the Chinese government against Uighurs.

In an interview that the author conducted with Mochamad Aziz as chairman of the Muhammadiyah Special Branch in China, he revealed that there was indeed a need for a counter-discourse to fight the mainstream discourse in the country when the issue of the Chinese government's repressive actions against the Uighurs broke out in the country. There is a concern from the Chinese Muhammadiyah that if this condition is allowed to drag on, it will result in an unfavorable future situation, including that it could endanger the fate of Indonesian citizens who are currently continuing their studies in China.

One of the biggest concerns is that if relations between the two countries deteriorate because of this issue, which is getting more and more viral out of control without a rival problem conforming to the actual situation, then what will the fate of Indonesian students in China number in the thousands and many of these students who study in China using a full scholarship facility from the Chinese government. So don't let the issue of the Chinese government's repressive behavior towards the Uighurs go viral wildly.

For this reason, a joint movement within Muhammadiyah cadres in China emerged to try to reduce the negative issue that had gone viral without showing partiality to any group.

Muhammadiyah members in China emphasize that the Chinese government can accept Islam and ask people in Indonesia not to be too fussed about viral repressive behavior that often uploads Muslims' lives who walk safely and comfortably in China. As uploaded by Zalik Nuryana as Chair of the Library and Information Council of the Chinese Muhammadiyah domiciled in Nanjing, 
Journal of Social Studies (JSS), Volume 16, Number 1, 2020: 51-64

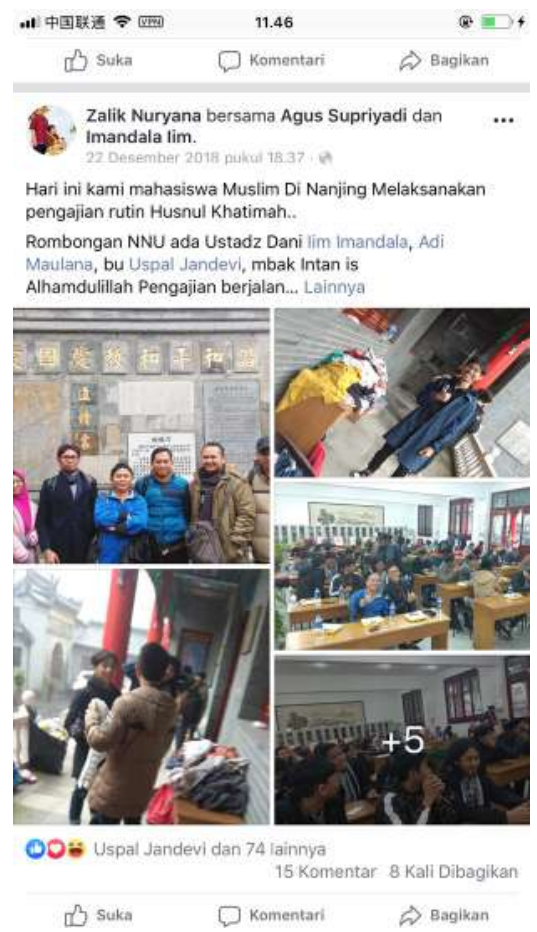

Image 1: Zalik Nuryana's social media upload

The above upload is precisely two weeks after the Chinese government's repressive actions against the Uighurs began to go viral in Indonesia. In this upload, Zalik Nuryana showed that Muslims in China could carry out recitation in a quiet mosque, usually done by Muslims in Indonesia. From the narrative that is built based on a series of words and even the images, it also supports the safe and comfortable atmosphere to be conveyed.

When interviewed, Zalik Nuryana revealed many questions in a group chat and private messages asking him how conditions were in China, whether he had experienced things like viral news so far. The status post he did was also an answer that what he shared with other Muslims in China was no different from what Indonesian Muslims did in carrying out rituals and religious meetings.

He wants to emphasize that in a country known for its strong communist ideology, China provides good facilities to religious people who want to carry out their sharia. It can be seen in the message uploaded that the recitation of Chinese Muslims can be attended by many people, even to the point of being able to distribute staples freely and openly. 


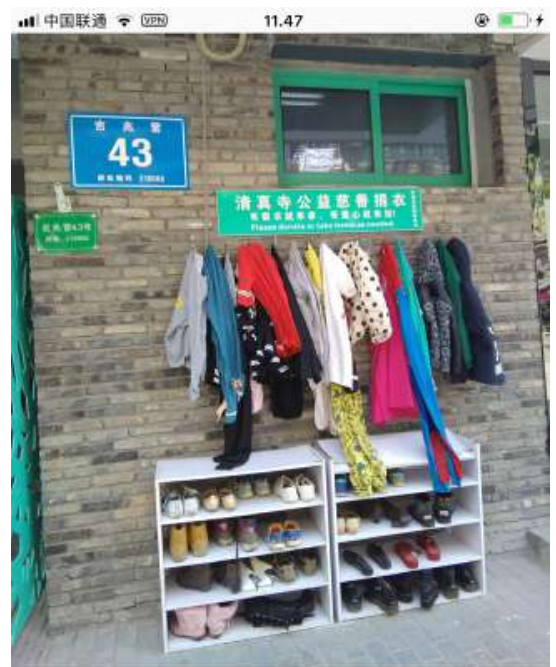

Imandala lim

Posting lagi ah... mumpung nyantei. Kali ini tentang bersedekah pakaian layak pakai di salah satu masjid Kota Nanjing China. Sedekah pakaian layak pakai ini diinisiasi oleh pengurus masjid dengan cara menyediakan space secukupnya di dekat pintu gerbang masjid. Siapa pun orang boleh menyimpan pakaian layak pakai dan siapa pun boleh mengambil. Foto diambil tahun 2016. Jadi jangan kira kami tidak peduli sesama dan menuduh kami mati rasa. Kami juga peduli dan kami juga punya ulama.

\section{Image 2: Postingan Imandala}

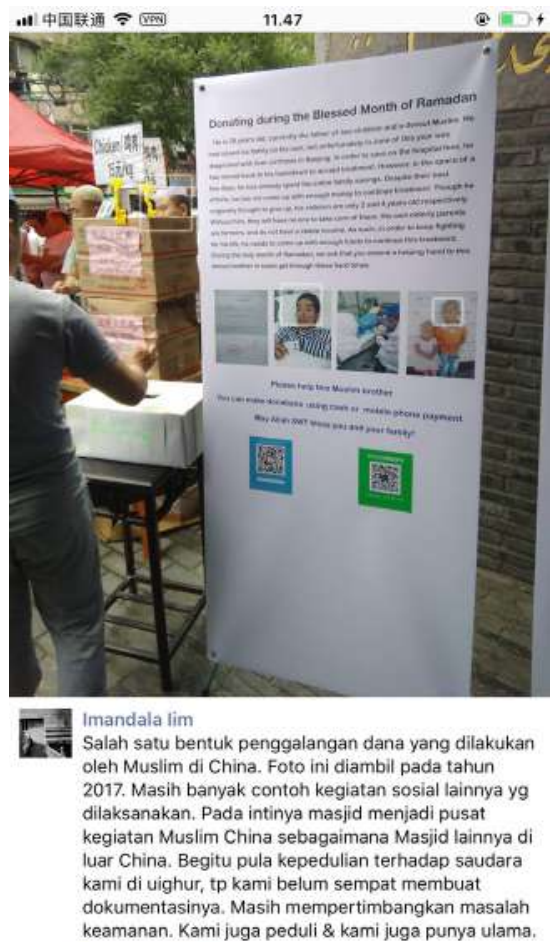

Image 3: Imandala's social media upload

Then there is also a post from Imandala, an activist of Islamic studies in China, the Board of Trustees for the Association of Indonesian Chinese Students. Imandala uploaded statuses on social media regarding that Muslims in China, both Chinese citizens and non-Chinese citizens such as Indonesia, still have the spirit of Islamic brotherhood.

The narrative was built because, based on his observations, there is an assumption that Muslims in China do not have the spirit of Islamic brotherhood because they do not want to care about what happens to ethnic Uighurs who are predominantly Muslim. There are allegations that Indonesian students who are Muslim are more siding with China because while continuing their studies, they always receive various facilities from communist China.

In his social media uploads, Imandala builds a discourse that Muslims in China are always active in giving alms and raising funds and other assistance for others in need. Still, in addressing China and the Uighurs' problems, they 
must be careful because it is not a simple problem because already concerning the sovereignty of a nation.

Still, according to Imandala, the scholars in China have a long-term plan so that Islamic da'wah can be accepted by all Chinese citizens in the future. Therefore, all Muslims from all over the world should provide support; one of the best supports is not to give a negative image of Islam to the Chinese government. Meanwhile, most Muslims' sporadic response in Indonesia to the viral issue of the Chinese government's repressive behavior towards ethnic Uighurs, which still cannot be confirmed, has the potential to damage the image of Islam in front of the Chinese government. And this will automatically make it difficult to preach Islam by Chinese scholars in their own country.

Then there is also a post from Agus Supriyadi, a Muhammadiyah cadre who is also the Board of Trustees of the Indonesian Helping movement organization. Agus Supriyadi emphasized inviting Indonesian Muslims to reflect on China. A country known for its strong communist ideology can facilitate worshipers with special needs in all mosques in China without exception, then is Indonesia the largest Muslim country in China? The world has already done it.

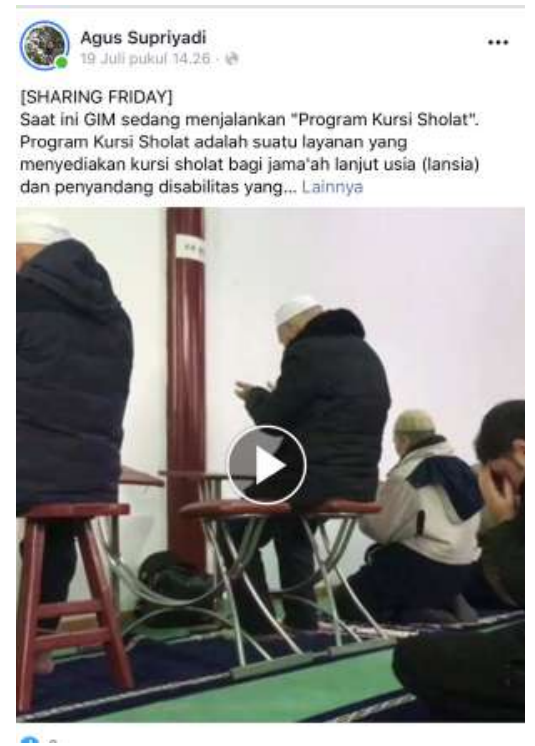

Image 3: Agus Supriyadi's social media upload

After the viral issue of the Chinese government's repressive behavior towards the Uighurs, Agus Supriyadi immediately coordinated with the 
Indonesian Assistance Movement organization, which he guided to find out what simple but extraordinary things had been done by Chinese Muslims and had not been maximally implemented in Indonesia. Finally, Agus Supriyadi realized a phenomenon of procuring unique prayer chairs that can facilitate worshipers with special needs and the elderly to carry out prayer movements while assembling in the mosque. The chairs provided are not ordinary in general but are designed in such a way as to facilitate each prayer movement for congregations with special needs and the elderly. A phenomenon that is difficult to find in Indonesia.

This condition was used by Agus Supriyadi to invite Muslims in Indonesia to conduct self-reflection. The message to be conveyed is that Indonesian Muslims should not be too sporadic in addressing an issue whose truth is unknown. According to Agus Supriyadi, until now there is still no reputable national and international institution to officially confirm the validity of this negative viral issue, so it would be nice if Indonesian Muslims catch up in providing facilities for older adults and people with special needs who want to worship at the mosque.

If Alexander Wendt revealed that if anarchy within a nation could be created, then at that time, actually harmony was also something that could be made. The effort to inject counterparts from the Chinese Muhammadiyah cadres through their various uploads on social media is their effort to construct this harmony.

The social media behavior of the Muhammadiyah members in China is also in line with the variant of the International Society Centric reconstruction, wherewith its status as a global organization that at the same time domiciles directly in the area that is the subject of the issue, what they do is expected to be a match for The viral mainstream issue states that human rights violations have occurred in the repressive behavior committed by the Chinese Government against the Uighurs. The simple logic is, if those who are in Tiion China do not feel that a negative viral issue is happening, how can people who are not in China easily believe that there have been human rights violations there.

Chinese Muhammadiyah cadres also regretted the existence of Muhammadiyah cadres in the country who were also carried away by the mainstream viral issue of irresponsible accounts and contributed to heating the domestic situation, even though they had official representatives domiciled directly in China. What is done by Muslims in Indonesia who randomly accept negative viral issues can be included in the Radical Constructivism variant, which 
no longer respects the sovereignty of a nation, as seen from the development of narratives that contain hatred for individual countries.

However, these Muhammadiyah members' struggle in providing an optional discourse against mainstream discourse in the country is not easy. Because in addition to having to be prepared to fight attacks from fellow Indonesian citizens who believe that when negative information goes viral, the blocking of various kinds of mainstream social media widely used by Indonesian citizens in the country is an obstacle in itself. Social media, like Facebook, Instagram, Twitter, Youtube, WhatsApp, cannot be accessed in China. To be able to access them, you must first activate a Virtual Private Network (VPN), and VPN cannot always be activated in China.

\section{Conclusion}

Muhammadiyah members and sympathizers in China have behaved appropriately when using social media to respond to the viral issue of the Chinese government's repressive actions against ethnic Uighurs. Efforts to reduce the mass anxiety over this unknown validity of information without taking sides with any party is the best way. Showing goodness and publishing it and providing a challenge to compete in that kindness is a diplomatic step that is smooth and smart.

Put, a viral issue that is believed by the country's people is proof that the low level of media literacy for the Indonesian nation needs to be intensified and the seriousness of work by various institutions that are aware of the importance of media literacy. The difficulties may no longer distinguish, which is the real reality and the pseudo-reality on social media. Muhammadiyah members and sympathizers in China and other countries should be concerned if they have to confirm various things that happen to be viral in the country and have the potential to complicate an unharmonic atmosphere.

\section{References}

Amindoni, A. (2019). Muslim Uighur: Mengapa ormas Islam dan pemerintah Indonesia "bungkam" atas dugaan pelanggaran HAM di Xinjiang? BBC Indonesia. https://www.bbc.com/indonesia/indonesia-50835364

Fadillah, D. (2020). Belt road initiative in the simulacra analysis (IndonesiaChina relationship in the perspective of Indonesian students in Nanjing 
City). ASPIKOM, 5(1), 63-71.http://dx.doi.org/10.24329/aspikom. v5i1.493

Fadillah, D., Nuryana, Z., \& -, S. (2020). Public Opinion of the facial recognition policy in China by Indonesian student in Nanjing City. International Journal of Psychosocial Rehabilitation, 24(04), 1645-1652. https://doi. org/10.37200/IJPR/V24I4/PR201272

Hobson, J. (2000). The state and international relations. Cambridge University Press.

Idhom, A. (2019). Klarifikasi Dubes China soal Uighur saat bertemu Moeldoko. Tirto. Id. https://tirto.id/klarifikasi-dubes-china-soal-uighur-saat-bertemumoeldoko-enDn accessed 11 January 2020.

Jandevi, U. (2019). New media for increasing political participation in Indonesia. International Journal of Communication and Society, 1(1), 1-8. https://doi. org/10.31763/ijcs.v1i1.19

Lotan, F. F. (2019). Making a positive internet through Socmed Agawe Guyub. International Journal of Communication and Society, 1(1), 9-16. https://doi. org/10.31763/ijcs.v1i1.22

Makki, S. (2018). Protes persekusi Uighur, alumni 212 desak Dubes China diusir. CNN Indonesia. https://www.cnnindonesia.com/ internasional/20181221152441-106-355532/protes-persekusi-uighuralumni-212-desak-dubes-china-diusir accessed 17 February 2020.

Meredith, R. (2007). The elephant and the dragon: The rise of India and China and what it means for all of Us. W. W. Norton \& Company, Inc.

Nau, H. (2009). Perspective on international relations 2ed. CQ Press.

Rachmawati, I. (2012). Konstruktivisme sebagai pendekatan alternatif dalam hubungan internasional. PARADIGMA: Jurnal Masalah Sosial, Politik Dan Kebijakan, 16(1), 25-34. https://doi.org/https://doi.org/10.31315/ paradigma.v16i1.2456

Suastha, R. D. (2018). Dubes China sebut pemberitaan soal Uighur sesat. CNN Indonesia. https://www.cnnindonesia.com/ internasional/20181228163043-106-357082/dubes-china-sebutpemberitaan-soal-uighur-sesat accessed 29 December 2019.

Sugiyono. (2013). Manajemen metode penelitian. Bandung: Alfabeta.

Sugiyono. (2016). Memahami penelitian kualitatif. Bandung: Alfabeta.

Ulfah, M., \& Barry, A. (2019). Indonesia leader forum, post-truth and 
Journal of Social Studies (JSS), Volume 16, Number 1, 2020: 51-64

political interests in social media and television. International Journal of Communication and Society, 1(1), 17-25. https://doi.org/10.31763/ijcs. v1i1.18 